\title{
Aqua-Feed Wastes: Impact on Natural Systems and Practical Mitigations-A Review
}

\author{
Jonathan M. Munguti ${ }^{1}$, James G. Kirimi ${ }^{2}$, Kevin O. Obiero ${ }^{3}$, Erick O. Ogello ${ }^{4}$, Domitila N. Kyule ${ }^{1}$, \\ David M. Liti ${ }^{5} \&$ Levi M. Musalia ${ }^{6}$ \\ ${ }^{1}$ National Aquaculture Research Development \& Training Center, Kenya Marine and Fisheries Research \\ Institute, Sagana, Kenya \\ ${ }^{2}$ Department of Animal Sciences, Chuka University, Chuka, Kenya \\ ${ }^{3}$ Kenya Marine \& Fisheries Research Institute, Sangoro Aquaculture Research Station, Pap-Onditi, Kenya \\ ${ }^{4}$ Department Biological Sciences, University of Eldoret, Eldoret, Kenya \\ ${ }^{5}$ Department of Fisheries and Natural Resources, Maseno University, Maseno, Kenya \\ ${ }^{6}$ Department of Dryland Farming and Natural Resources, Tharaka University College, Marimanti, Kenya \\ Correspondence: Jonathan M. Munguti, National Aquaculture Research Development \& Training Center \\ (NARDTC), Kenya Marine and Fisheries Research Institute, P.O. Box 451-10230, Sagana, Kenya. E-mail: \\ jmunguti2000@gmail.com
}

Received: October 17, 2020

Accepted: November 19, 2020

Online Published: December 15, 2020

doi:10.5539/jas.v13n1p111

URL: https://doi.org/10.5539/jas.v13n1p111

\begin{abstract}
Dietary composition of aquaculture feeds (aquafeeds) determines the quality of wastes from aquaculture production systems. These wastes, which are derived mainly from nitrogenous and phosphorus compounds subsequently affect water quality in the culture systems and the ambient environment. Depending on the type of culture systems and management practices employed, the aquafeed wastes can influence the water $\mathrm{pH}$, algal turbidity, biological oxygen demand (BOD) and may cause fish mortality. The aquafeed wastes also can facilitate eutrophication leading into harmful algal blooms. Moreover, large quantities of aqua-waste are discharged as fish cannot retain all the food they consume which means a significant portion of the feed remains uneaten. In this paper, we review and discuss practical nutritional strategies and mitigation measures to reduce aquafeed wastes including controlled formulation using high-quality ingredients, enzyme-based aquafeed, processing, reduction of anti-nutrition factors and precision feeding. The paper further recommends strategies for enhancing the resilience of aquaculture production systems and mitigation measures to reduce the effects of aqua-wastes on ambient natural environments.
\end{abstract}

Keywords: aqua-feed, aqua-wastes, nitrogen, nutrient discharge, nutritional strategies, phosphorus

\section{Introduction}

Aquaculture remains a lucrative endeavour, as the world seeks to feed itself (FAO, 2014). The sector plays a significant role in contributing to food and nutritional needs of a ballooning world population, which in turn fosters food security and economic growth through value-chain linkages (Ogello \& Munguti, 2016; Obiero et al., 2019). Yet, aquaculture presents a range of environmental challenges, which vary by production system and can result in serious ecological footprint especially for intensive systems (Alleway et al., 2019). Therefore, there is a need to formulate new strategies to ensure sustainability in production with minimal negative impacts on the environment (Hasan, 2001; Naylor et al., 2001). Thus, aquaculture enterprises must focus on reducing production costs, improving the efficiency of the production systems and promoting environmental sustainability (Musyoka et al., 2019; Waite et al., 2014).

Over the past decade, fish production in Kenya increased from about 5,000 metric tonnes (MT) in 2009 to nearly 19,000 MT in 2019 (Figure 1) (KNBS, 2019). The implementation of Economic Stimulus Programme between 2009-2013 boosted farmed fish production and triggered a demand for formulated fish feeds estimated at 30,000 MT that would not be adequately and timely supplied by the private sector (Munguti et al., 2014). This motivated some farmers to put up their own ponds, further boosting the demand for feed to over 100,000 MT, 
(Charo-Karisa \& Gichuri, 2010). The enhanced aquaculture production in turn precipitated a higher demand for inputs. Subsequently, this led to increased generation of aqua-waste from production systems (Dauda et al., 2019).

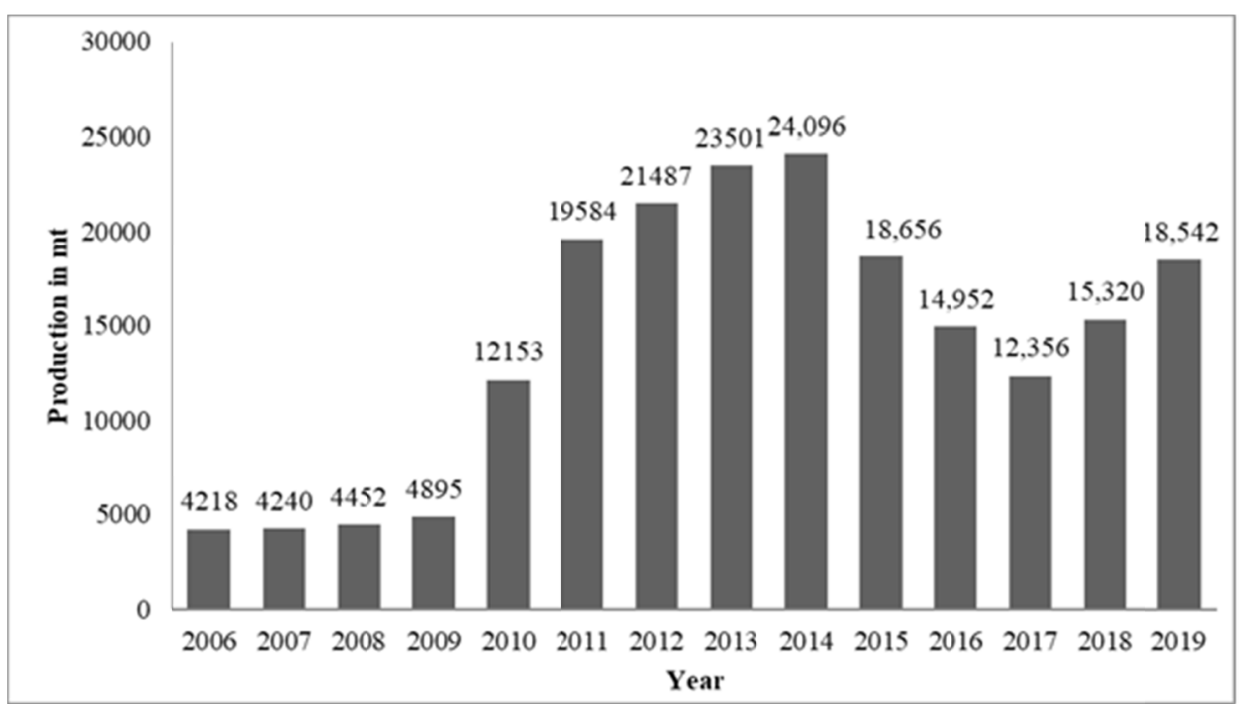

Figure 1. Trends in aquaculture production in Kenya 2006-2019 (KNBS, 2019)

Fish production in Kenya is uneven. In the intensive and semi-intensive aquaculture systems, a considerable amount of organic waste emanates from uneaten food and faeces. The soluble substances or excreta, in turn heighten chemical and biological oxygen demands (White, 2013). Consequently, eutrophication of water bodies is vital, as it fosters environmentally friendly and sustainable aquaculture techniques. The concentration levels and carrying capacity of the recipient ecosystem determine whether a nutrient turns into a pollutant or not. Phosphorus is typically the limiting nutrient (Hudson et al., 2000) in freshwater ecosystems, so its addition promotes primary production (algal growth). By contrast, nitrogen is typically the limiting nutrient in marine environments (Howarth \& Marino, 2006). This paper reviews the current aspects of nutrients loading into and release of aquafeeds from different fish culture systems in Kenya and proposes ways to mitigate their harmful impacts.

\section{Major Nutrients in the Discharge of Aquaculture Systems}

In aquaculture, feed is the major source of organic waste (Dauda et al., 2019). The two major types of wastes from fish feed can be classified into solid and dissolved waste. Solid waste is primarily derived from the uneaten feed and faecal droppings of cultured fish and carcasses of dead fish (Akinwole et al., 2016). Dissolved wastes of major concern are Nitrogen $(\mathrm{N})$ and Phosphorus $(\mathrm{P})$ compounds, which are products of food metabolism in fish or decomposed uneaten feed. These two elements (N and $\mathrm{P}$ ) constitute important components of protein, which is the main portion of aquafeed. Olsen et al. (2008) reported that $\mathrm{N}$ and $\mathrm{P}$ are not toxins, but biogenic elements, which are potentially harmful in the natural systems only if their supply exceeds the assimilation capacity of the ambient ecosystem.

\subsection{Nitrogen}

Protein in fish feed serves as a double-edged sword: it is the priciest component but also the main source of nitrogenous pollution in fish culture environment. The saving grace is that fish can utilise protein very efficiently, utilising a good chunk of digestible protein to generate energy and large amounts of nitrogenous metabolites. Nearly one-third of Nitrogen (N) supplied in feed is retained (Jirasek et al., 2005). This is an indispensable element for algae growth. One drawback is that high $\mathrm{N}$ concentrations in natural waters contribute to eutrophication. Furthermore, after metabolism, all the amino acids that are not retained are excreted into the environment as soluble inorganic nitrogen compounds ( $\mathrm{Li}$ et al., 2009). The processes that transform ammonia to nitrite and nitrate consume oxygen, which depletes oxygen in the environment (Coldebella et al., 2018). Ammonia is the predominant type of $\mathrm{N}$ excreted. High ammonia excretion may be triggered by high protein intake or inadequately formulated diets, which lead to unbalanced protein synthesis. Dissolved nitrogen waste, on the other hand, can be minimised by balancing protein and energy, which has the positive impact of fish using 
non-protein sources as energy. This could improve protein retention in fish (Keshavanath et al., 2002), thereby reducing nitrogenous wastes.

\subsection{Phosphorus}

Phosphorus (P) is the major component in nucleic acids and cell membranes, and it's involved in all energy-producing cellular reactions (NRC, 1993). Phosphorus is also vital in carbohydrate, lipid, and amino acid metabolism. It's also useful in other metabolic processes involving buffers in body fluids. It's worth noting feed is the main source of phosphate for fish since the concentration of phosphate is low in natural waters (NRC, 1993). However, rations must meet fish requirements in adequate concentrations, as fish can absorb $P$ from water but dietary supplementation is necessary due to low water borne $\mathrm{P}$ concentrations. Because fish is a monogastric animal, the retention of dietary $\mathrm{P}$ is only about $20 \%$, while the rest (68-86\%) is usually excreted (Crab et al., 2007; Lazzari \& Baldisserotto, 2008).

Subsequently, excess $\mathrm{P}$ in aquafeed yields in higher levels of excreted P. This is a major cause of eutrophication in ponds (Jahan et al., 2003), often resulting in impaired water quality downstream. Dietary available P required for optimum growth, feed utilisation and bone mineralisation for rainbow trout and other fishes range from 0.4 to 0.8\% (Sugiura et al., 2000; NRC, 1993). Phosporus retention is also affected by the growth rate. Higher values are obtained when growth performances are good (Jahan et al., 2002). In fish, a certain amount of non-faecal P excretion is inevitable. It occurs even at zero intake of P. Consequently, non-faecal P excretion is unaffected by $\mathrm{P}$ intake up to the level required by the animal (Rodehutscord et al., 2000).

\section{Aquaculture Production Systems in Kenya and Their Potential for Nutrients Discharge}

Aquaculture entails rearing and production of fish and other aquatic animal and plant species under controlled conditions. Many aquatic species have been cultured, including fish, crustaceans and molluscs and aquatic plants and algae. Aquaculture production methods have been developed in Kenya and adapted to suit environmental and climatic conditions. The four major categories of aquaculture systems are extensive fish farming system, semi-intensive systems and intensive systems. These systems vary in the manner water is used and the characteristics of the associated "waste" by-products (Dauda et al., 2019).

\subsection{Extensive Fish Farming}

The system is primarily conducted in dams and water reservoirs. The fish are left in low density over a large culture area and fed on naturally occurring organisms, with some aid from pond fertilisation (Ajani et al., 2011). The farmed fishes depend on the primary productivity of the culture water and no artificial feed is given. Consequently, there is minimal potential for nutrients discharge because no supplemental feed is given to fish.

\subsection{Semi-intensive Systems}

Semi-intensive farming is the main culture system in Kenya and it comprises earthen and liner ponds. In this aquaculture system, feed costs typically account for around 40 to 60 percent of production costs (Liti et al., 2006). Fish are stocked at a moderate to relatively high density. They rely on both feeds from natural production and supplemental feed (Dauda et al., 2017).

\subsubsection{Pond Culture}

Pond culture is the most prevalent and the traditional system of fish culture rearing method in Kenya. Most fish farmers practising pond culture add manure or inorganic fertilizer to ponds to increase the supply of natural food organisms to the fish, thereby reduce production costs arising from the use of supplemental feeds (Mbugua, 2008). Over 90 per cent of cultured fish in Kenya come from earthen ponds, which range in size from 150 to 500 $\mathrm{m}^{2}$ (Ngugi et al., 2007). Ponds rely mainly on internal natural processes to purify the water in the pond systems and a large proportion of the waste is confined within the pond, with some of the organic waste mineralised in situ (Verdegem et al., 2001). The biological community acts on the dissolved wastes. This in turn helps to stabilize and recycle waste. The ammonia is converted by Nitrobacter and Nitrosomonas to become less toxic nitrate. The nitrate and phosphate in the waste in turn serve as nutrients for the phytoplankton and macroalgae in the pond ecosystem. However, the pond system's ability to manage wastes is limited and depends directly on the amount of waste that is recycled by the pond on a daily basis (Tucker et al., 2001), while solids accumulate and undergo microbial decomposition in the bottom of the pond. Nutrient outflow may not ordinarily pose serious problems during the growing season when discharge is minimal, but pond draining preceding the annual harvest and during harvesting operations can increase waste significantly, loading in-receiving waters due to disturbance of the pond sediments. The excess of organic matter in the ponds' sediment and the lack of conditions for decomposition could potentially cause an imbalance in the nitrification and denitrification processes. This contributes to the accumulation of toxic ammonia and nitrite during cultivation (Hargreaves \& Tucker, 2004; 
Durborow et al., 1997). The sediment in turn over may trigger an increase in nitrogenous and phosphate compounds and elevate Chemical Oxygen Demand (COD) levels. The use of decantation ponds is an effective practice reducing the concentration of these solids (Coldebella et al., 2018). Small and large ponds do not present significant differences in the quality of effluents. However, medium size ponds showed poor effluent quality (Coldebella et al., 2018).

\subsection{Intensive Systems}

The intensive systems practised in Kenya typically include recirculating aquaculture systems (RAS), raceways, cages and net pens. While intensive systems rely on large amounts of supplementary or complete feeds and supply of external inputs and technologies targeted towards fast growth (Ajani et al., 2011; Naylor et al., 2001). In recent years, fish operations in Kenya have shifted towards intensive farming systems. These changes involve an increase in culture density and a decrease in the consumption of water. In integrated intensive aquaculture systems, the waste load such as nitrates and phosphates can be reduced if the fish is cultured with other organisms, while plants are used as a biofilter, which often converts nutrient discharges into valuable products (Turcios \& Papenbrock, 2014). Notably, intensive farming systems can impact the environment mainly due to residues related to food left overs and faeces produced by fishes. These residues are primary sources of $\mathrm{N}$ and $\mathrm{P}$, the principal nutrients responsible for eutrophication in freshwater ecosystems.

\subsubsection{Raceways}

This system is mainly used in the production of rainbow trout (Oncorhynchus mykiss). The potentially negative impact of effluents in raceways is occasioned by failure to control suspended and settleable solids from leaving the facilities. The degree of impact can be reduced significantly by enhancing feed quality, improving feeding efficiency and effective solids capture and handling (Hinshaw \& Fornshell, 2002).

\subsubsection{Recirculating Aquaculture Systems (RAS)}

Recirculating aquaculture systems (RAS) are usually indoor tank-based systems. They achieve high rates of water re-use by mechanical, biological chemical filtration and other treatment steps. The RAS in Kenya are primarily used for culturing Nile tilapia (Oreochromis niloticus) and African catfish (Clarius gariepinus). Fish are typically reared in tanks indoors or under greenhouses. The RAS is designed utilise minimal water, control culture conditions and allow waste products to be fully managed. They generally incorporate components that efficiently collect and remove solid waste, aerate or oxygenate the water, and reduce the build-up of toxic metabolites (Chen et al., 2002).

\subsubsection{Cages and Net Pens}

In-situ production of farmed aquatic organisms in caged enclosures is a relatively recent practice in aquaculture innovation in Kenya. Cage culture development increased from around 2013 and currently plays an important role in rejuvenating fish supply to urban and rural consumers (Aura et al., 2018; Njiru et al., 2018). Cages or net-pens hold fish at relatively high density and are often sited in a much larger body of water, where fish are fed a formulated diet. Settled waste passes through the bottom of the pen and is diluted in the surrounding waters. Ordinarily, dissolved nutrients are dispersed rapidly and utilised by bacteria, phytoplankton and zooplankton. However, if there are high levels of nutrients released continuously, this could potentially lead to eutrophication and or algal blooms. In Kenya, cage farming is growing fast in Lake Victoria, with the highest number of cages reported in Siaya County (Aura et al., 2018). However, one drawback associated with cage farming is increased nutrient loss from the uneaten feed, faecal wastes and excreta from cage-reared fish and possible negative impacts upon water quality and surrounding aquatic environment and ecosystem health (Mente et al., 2006; Leon, 2006). Waste feed increases eutrophication and enhances the growth of algae and water hyacinth in and around the fresh water lake. Recent, though isolated cases of fish kills were attributed to low dissolved oxygen concentrations $(<0.64 \mathrm{mg} / \mathrm{L})$, increased cases of fish disease were signs of poor management practices among cage farmers (Njiru et al., 2018).

Mariculture in sea cages has been associated with the deterioration of water quality and eutrophication of coastal waters in fish cage culture, as water passes freely through the nets. The distribution of the nutrients, on the other hand, is highly influenced by the hydrodynamics of the cage location. All excess nutrients are released to the environment, increasing the dissolved nutrient concentration in the water body and enriching the sediment beneath the cages. If the environment is unable to assimilate these nutrients fast enough, they tend to accumulate, causing eutrophication and changes in benthic abundance and biodiversity. Wastes from feeds used in cages in Lake Victoria have been associated with increased eutrophication and promoting the growth of algae and water 
hyacinth in the lake. On the contrary, Islam (2005) argues that although nutrient loading still occurs in cage farming, its main cause is due to too many cages concentrated together, rather than poor feeding practices.

\section{Approaches to Mitigate Nutrients Discharged Into the Environment}

Most intensive and semi-intensive aquaculture production systems rely heavily on formulated diets. Research efforts on nutrition and feeding management strategies must play a key role in the sustainable development of the aquaculture sector (Hernandez \& Roman, 2016). Several recommendations and approaches to mitigate impacts of eutrophication have been explored, including feed formulation, feeding management practices, system designs, site selection, effluent treatment and recovery of uneaten feed and dead fish. However, the primary solution for managing the environmental impacts of aquaculture lies in the management of feed (Turcios \& Papenbrock, 2014).

\subsection{Nutritional Strategies}

Nutritional strategies to minimise the impact of aquaculture waste on aquatic environments are multiple, and include improvement, manipulating and formulating diets without affecting growth and production efficiency. This involves selecting raw materials with high dry matter digestibility, or use of feed additives to improve the apparent digestibility. Other strategies include processing ingredients, adopting more effective feed management practices for particular fish species; recovering unconsumed feeds, and selecting fish species and strains with higher feed efficiency and better nutrient utilization (Amirkolaie, 2011).

\subsubsection{Diet Formulation}

The primary objective in diet formulation for fish is to provide a nutritionally balanced mixture of ingredients to support their maintenance, growth, reproduction, and health at an acceptable cost and have minimum effect on water quality in the culture system (NRC, 1993). According to Kirimi et al. (2020), fish feed quality depends on the number of essential amino acids and the balance among the respective amino acids, which in turn determine the utilisation of the protein. Feeding excess of amino acids could lead to amino acid catabolism with associated ammonia excretion and loss of energy. Dissolved nitrogen waste can be reduced by ensuring a balance between protein intake and energy utilization. To reduce phosphorus excretion in animal production, formulation of diets based on available P rather than total phosphorus is necessary (Lynch \& Caffrey, 1997). Feeds with adequate concentrations of available $\mathrm{P}$ decrease the excretion and release of phosphorus in the environment, which improves water quality. Nitrogen pollution arising from fish feed can also be reduced by applying the concept of ideal protein when formulating the fish feed. This concept was developed in the late 1950s and 1960s, where the main goal was to provide a combination of indispensable amino acids that precisely meets an animal's requirements for protein accretion and maintenance while avoiding deficiencies or excesses (Emmert \& Baker, 1997).

Nitrogen pollution from the fish feed can be reduced by replacing protein with synthetic amino acids. Nitrogen is supplied through the crude protein (CP) content in the diet. As CP content in the diet increases, $\mathrm{N}$ concentration rises similarly. However, fish do not require $\mathrm{CP}$ per se; instead, they need amino acids (the building blocks of protein) in specific amounts and combinations for efficient production. Reducing the $\mathrm{CP}(\mathrm{N})$ content in the diet, with supplementation of crystalline amino acids is one of the best methods to reduce $\mathrm{N}$ excretion. To avoid amino acid losses in fish due to unbalanced protein profiles, several authors have monitored the effects of supplementing feeds with industrial amino acids (Furuya et al., 2004; Nunes et al., 2014). They propose adding these supplements as it makes it possible to meet essential amino acid requirements more accurately. However, a drastic reduction in protein levels associated with the use of synthetic amino acids is not recommended as the minimum $\mathrm{N}$ contribution from protein must be considered (Gaye-Siessegger et al., 2007).

\subsubsection{Appropriate Choice of Ingredients}

Development of sustainable aquaculture primarily depends on the establishment of alternative feed stuffs to fish meal. The influence of supplementary fish feed on discharged water quality, on the other hand, depends on the composition and physical characteristics of the feed used (Hlavac et al., 2014). The introduction of highly digestible feed has reduced solid waste excretion. Further reductions can be achieved through a careful selection of the ingredients used. Appropriate choice of ingredients is primary used to achieve a reduction in $(\mathrm{P})$ and $(\mathrm{N})$ loading (Jahan et al., 2003). Use of multiple ingredients can provide a sufficient amount of the amino acid, despite the lower fish meal level. Adequate combination of alternative plant low P protein ingredients, mainly soybean meal, significantly reduces the P loading in diets without compromising the growth (Satoh et al., 2003). The need to formulate diets which minimize $\mathrm{P}$ excretion in fish and consequent eutrophication of the water requires the replacement of fish meal with low-P protein sources. The use of high protein ingredients that have a 
high percentage of digestible $\mathrm{P}$ may help to reduce the unavailable $\mathrm{P}$ concentration of the feed. According to Suryaningrum et al. (2017), evaluation of digestibility is key to determining material for feed ingredients. Feed containing high digestible ingredients is associated with better growth performance and lower feed waste that potentially pollutes the environment.

\subsubsection{Feed Processing}

One of the most effective ways of improving aquaculture effluent water quality is by modifying diets fed to culture fish. The use of extruded diets has proved to be an important facet in fish nutrition. Extruded diets possess higher stability and digestibility. This significantly reduces the amount of nutrients excreted into the rearing water (Johnsen et al., 1993). Floating feeds are often recommended for feeding tilapia as they are easier for the fish to see and eat than sinking pellets, which often end up as waste. This in turn leads to nutrient enrichment, thus enhancing eutrophication. To reduce lake pollution, extruded free-floating feeds should be utilized in place of sinking feeds (Njiru et al., 2018). Proper grinding, pelleting, and steam flaking of feed ingredients can increase nutrient availability, which reduces faecal loss. Thermal and mechanical treatment of feed cereals prior to application can also help reduce the amount of poorly or undigested feed (Hlavac et al., 2014; White et al., 2007).

\subsubsection{Use of Phytase Enzyme}

In aquaculture industry, fish meal is gradually being replaced with plant by product-based ingredients but use of these by products is nutritionally restrained because of phytate content, which is the main form of storage for phosphorus (P) in plants (Hussain et al., 2017). The majority of $\mathrm{P}$ in most protein-rich plant ingredients is bound in phytate, which limits bioavailability to most fish because they lack the digestive enzyme phytase (Jobling et al., 2001). Up to 80 per cent of the total P content in plant ingredients may be present as phytate (Ravindran et al., 1994). This fraction is practically unavailable for monogastric aquatic animals during digestion due to the lack of endogenous enzymes, which are benefitial for their efficient hydrolysis (Cao et al., 2007). Phytase is an enzyme known chemically as myo-inositol hexaphosphatephosphohydrolase (Class 3: Hydrolases) that may be present in some plant ingredients. Alternately, may be produced by microorganisms. It is specific to hydrolyse, the indigestible phytate present in plant protein sources. Excess level of dietary available P decreases the P retention rate (as a percentage of absorbed P) from the amount absorbed, which increases non-fecal P excretion (Jahan et al., 2002). Phytase can be utilised in fish feeds by pre-treating feedstuffs, or incorporating it during diet preparation, or spraying onto pellets (Portz \& Liebert, 2004; Vielma et al., 2002). Phytase supplemented fish feeds have been generally reported to improve the bio-availability and utilization of plant phosphorus by fish (Cao et al., 2007). Furthermore, better use of nutrients results in the discharge of less phosphorous into the aquatic environment (Baruah et al., 2004). However, optimum level of its supplementation varies depending on its source, fish species; feed processing technology and phytate concentration in the diet (Hussain et al., 2017). The inclusion of microbial phytase in feed is meant to increase phytic phosphorus bioavailability, which reduces or fully replaces the use of inorganic phosphorus supplements (Cao et al., 2008).

\subsubsection{Reducing Anti-nutritional Factors}

Plant protein feedstuffs are increasingly being used in fish diets to reduce the dependence on fish meal and other animal protein feedstuffs, to keep feed costs in aquaculture down. Although most plant ingredients are readily available at lower cost than fishmeal, their use within aqua feeds is usually restricted by a relatively low protein content, unbalanced essential amino acid profile and presence of one or more anti nutritional factors (NRC, 1993; Kirimi et al., 2020). Antinutrients factors (ANFs) are defined as substances which by themselves or through their metabolic products arise in living systems, interfere with food utilisation and affect the health and production of animals (Makkar, 1993). Digestibility and absorption of protein is hampered when these ANFs are present. Elimination of ANFs from the feed and better processing conditions can enhance $\mathrm{N}$ utilization and consequently reduce $\mathrm{N}$ excretion.

\subsubsection{Match Supply of Available Nutrients to Requirements (Precision Feeding)}

Feeding fish to meet their nutrient requirements is key to minimising nutrient output. Over or underfeeding nutrients risks increasing output since animals will simply excrete all of the nutrients they are unable to utilise for maintenance and growth. The release of dissolved and suspended $\mathrm{N}$ and $\mathrm{P}$ can be significantly reduced through precise knowledge of the requirements of the fish and the supplying them appropriately (Kaushik, 1998). The other benefit of matching the nutrient concentration of the diet to the nutrient needs of the fish can reduce nutrient excretion, reducing the concentration of nutrients in faeces. 


\subsection{Feeding Management Practices}

Optimised aquafeeds have long been a major concern of the sustainable aquaculture development. Not only should feed composition meet the nutritional requirements of the fish, it should be reasonably managed (feed ration and feeding frequency) to enhance feed utilisation efficiency, growth performance and decrease the amount of wastes (Azaza \& Dhraief, 2020). One of the greatest causes of excess nutrients entering the environment is overfeeding due to the use of poor feeding strategy. Undoubtedly, profitability of commercial farming operation is key to all farmers. This means adopting appropriate feed management strategies to ensure feed use is optimised for maximum returns. While maximum growth rates can be attained by feeding to satiation, over or under-feeding results in poor feed management practices (White, 2013). Underfeeding lowers growth rates because of lower protein intake and promotes size heterogeneity. Optimisation of feeding strategies requires the calculation of appropriate ration sizes, feeding rates and feeding frequencies.

\subsection{System Design}

\subsubsection{Recirculatory System With Aquaponics}

Aquaponics, the combined production of fish in recirculated aquaculture systems and hydroponically grown plants, has gained popularity in recent years due to its sustainability. Aquacultural waste contains $\mathrm{N}$ (in the form of ammonia and nitrate) and P (mainly in the form of phosphate). These are essential nutrients for plant growth (Yildiz et al., 2017). In an aquaponic unit, water flows from the fish tank through filters, plant grow beds and then back to the fish. In the filters, the fish wastes are removed from the water, first using a mechanical filter that removes solid wastes, and then through a biofilter that clears the dissolved wastes. The biofilter provides a location for bacteria convertion of ammonia, which is toxic for fish, into nitrate, a more accessible nutrient for plants. This process is called nitrification. As the water (containing nitrate and other nutrients) travels through plant grow beds, the plants feed on these nutrients before the water returns to the fish tank purified. This process allows the fish, plants, and bacteria to thrive symbiotically and to create a healthy growing environment for each other. In aquaponics, the aquaculture effluent is diverted through plant beds and not released to the environment. At the same time the nutrients for the plants are supplied from a sustainable, cost-effective and non-chemical source.

\section{Conclusion}

This article has presented scholarly evidence on how aqua-feed contribute to nutrient pollution of ambient water bodies. Waste output from aquaculture operation to the aquatic ecosystem may be reduced but not completely eliminated as fish cannot retain all the food they consume, and even some part of the feed is left uneaten. Pollution can be highly reduced through appropriate nutritional strategies that increase feed conversion efficiency and reduced wastage in form of uneaten feed.

\section{References}

Ajani, E. K., Akinwole, A. O., \& Ayodele, I. A. (2011). Fundamentals of fish farming in Nigeria (p. 158). Wale Crown Publishers, Ibadan.

Akinwole, A. O., Dauda, A. B., \& Ololade, A. O. (2016). Haematological response of Clarias gariepinus juveniles reared in treated wastewater after waste solids removal using alum or Moringa oleifera seed powder. International Journal of Aquaculture, 6(11), 1-8. https://doi.org/10.5376/ija.2016.06.0011

Alleway, H. K., Gillies, C. L., Bishop, M. J., Gentry, R. R., Theuerkauf, S. J., \& Jones, R. (2019). The ecosystem services of marine aquaculture: Valuing benefits to people and nature. Bioscience, 69(1), 1-10. https://doi.org/10.1093/biosci/biy137

Amirkolaie, A. K. (2011). Reduction in the environmental impact of waste discharged by fish farms through feed and feeding. Reviews in Aquaculture, 3, 19-26. https://doi.org/10.1111/j.1753-5131.2010.01040.x

Aura, C. M., Musa, S., Yongo, E., Okechi, J. K., Njiru, J. M., \& Ogari, Z. (2018). Integration of mapping and socio-economic status of cage culture: Towards balancing lake-use and culture fisheries in Lake Victoria, Kenya. Aquaculture Research, 49, 532-545. https://doi.org/10.1111/are.13484

Azaza, M. S., \& Dhraief, M. N. (2020). Modeling the effects of water temperature on growth rates, gastric evacuation and the return of appetite in juvenile Nile tilapia, Oreochromis niloticus L. Journal of Agricultural Science, 12(8), 191-201. https://doi.org/10.5539/jas.v12n8p191

Baruah, K, Sahu N. P., Pal, A. K., \& Debnath, D. (2004). Dietary phytase: An ideal approach for cost effective and low-polluting aquafeed. NAGA, World Fish Center Quarterly, 27, 15-19. 
Cao, L., Wang, W., Yang, C., Yang, Y., Diana, J., Yakupitiyage, A., ... Li, D. (2007). Application of microbial phytase in fish feed. Enzyme and Microbial Technology, 14, 342-362.

Cao, L., Yang, Y., Wang, W. M., Yakupitiyge, A., Yaun, D. R., \& Diana, J. S. (2008). Effects of pretreatment with microbial phytase on phosphorous utilization and growth performance of Nile tilapia (Oreochromis niloticus). Aquaculture Nutrition, 14(2), 99-109. https://doi.org/10.1111/j.1365-2095.2007.00508.x

Charo-Karisa, H., \& Gichuri, M. (2010). Overview of the fish farming enterprise productivity program. End of year report fish farming enterprise productivity program phase I. Aquaculture Development Working Group, Ministry of Fisheries Development, Kenya.

Chen, S., Summerfelt, S., Losordo, T., \& Malone, R. (2002). Recirculating systems, effluents and treatments. In J. R. Tomasso (Ed.), Aquaculture and the Environment in the United States (Chap. 6, pp. 119-140). U.S. Aquaculture Society. A Chapter of the World Aquaculture Society, Baton Rouge, Louisiana.

Coldebella, A., Gentelini, A. L., Piana, P. A., Coldebella, P. F., Boscolo, W. R., \& Feiden, A. (2018). Effluents from fish farming ponds: A view from the perspective of its main components. Sustainability, 10(3). https://doi.org/10.3390/su10010003

Crab, R., Avnimelech, Y., Defoirt, T., Bossier, P., \& Verstraete, W. (2007). Nitrogen removal techniques in aquaculture for a sustainable production. Aquaculture, 270(1-4), 1-14. https://doi.org/10.1016/j.aquaculture. 2007.05.006

Dauda, A. B., Ajadi, A. L., Tola-Fabunmi, A. S., \& Akinwole, A. O. (2019). Waste production in aquaculture: Sources, components and managements in different culture systems. Aquaculture and Fisheries, 4, 81-88. https://doi.org/10.1016/j.aaf.2018.10.002

Dauda, A. B., Romano, N., Ebrahimi, M., Karim, M., Natrah, I., \& Kamarudin, M. S. (2017). Different carbon sources affected biofloc volume, water quality and the survival and physiology of African Catfish Clariasgariepinusfingerlings reared in intensive biofloc technology system. Fisheries Science, 83, 1037-1048. https://doi.org/10.1007/s12562-017-1144-7

Durborow, R. M., Crosby, D. M., \& Brunson, M. W. (1997). Ammonia in fish ponds. Journal of Fisheries Research Board Can, 32, 2379-2383.

Emmert, J. L., \& Baker, D. H. (1997). Use of the ideal protein concept for precision formulation of amino acid levels in broiler diets. Journal of Applied Poultry Research, 6(4), 462-470. https://doi.org/10.1093/japr/ 6.4.462

FAO. (2014). The state of world fisheries and aquaculture 2014. FAO, Rome, Italy.

FAO. (2019). Moving forward on food loss and waste reduction. The State of Food and Agriculture. FAO, Rome, Italy.

Furuya, W. M., Pezzato, L. E., Barros, M. M., Pezzato, A. C., Furuya, V. R. B., \& Miranda, E. C. (2004). Use of ideal protein concept for precision formulation of amino acid levels in fish-meal-free diets for juvenile Nile tilapia (Oreochromis niloticus L.). Aquaculture Research, 35(12), 1110-1116. https://doi.org/10.1111/ j.1365-2109.2004.01133.x

Gaye-Siessegger, J., Focken, U., Abel, H., \& Becker, K. (2007). Influence of dietary non-essential amino acid profile on growthperformance and amino acid metabolism of Nile tilapia, Oreochromis niloticus (L.). Comparative Biochemistry and Physiology Part A: Molecular and Integrative Physiology, 146(1), 71-77. https://doi.org/10.1016/j.cbpa.2006.09.025

Hargreaves, J. A., \& Tucker, C. S. (2004). Managing ammonia in fish ponds (Vol. 4603). Southern Regional Aquaculture Center Stoneville, Stoneville, MS, USA.

Hasan, M. R. (2001). Nutrition and feeding for sustainable aquaculture development in the third millennium. In R. P. Subasinghe, P. Bueno, M. J. Phillips, C. Hough, S. E. McGladdery, \& J. E. Arthur (Eds.), Aquaculture in the Third Millennium (pp. 193-219). FAO, Rome, Italy. https://doi.org/10.1057/9780333985557_13

Hernandez, A. J., \& Roman, D. (2016). Phosphorus and nitrogen utilization efficiency in rainbow trout (Oncorhynchus mykiss) fed diets with lupin (Lupinus albus) or soybean (Glycine max) meals as partial replacements to fish meal. Czech Journal of Animal Science, 61(2), 67-74. https://doi.org/10.17221/ 8729-CJAS 
Hinshaw, J. M., \& Fornshell, G. (2002). Effluents from raceways. In J. R. Tomasso (Ed.), Aquaculture and the environment in the United States (pp. 77-104). U.S. Aquaculture Society, A Chapter of the World Aquaculture Society, Baton Rouge, Louisiana.

Hlavac, D., Adamek, Z., Hartman, P., \& Masilko, J. (2014). Effects of supplementary feeding in carp ponds on discharge water quality: A review. Aquaculture International, 22, 299-320. https://doi.org/10.1007/s10499013-9718-6

Howarth, R. W., \& Marino, R. (2006). Nitrogen as the limiting nutrient for eutrophication in coastal marine ecosystems: Evolving views over three decades. Limnology and Oceanography, 51(1, Part 2), 364-376. https://doi.org/10.4319/lo.2006.51.1_part_2.0364

Hudson, J., Taylor, W., \& Schindler, D. (2000). Phosphate concentration in lakes. Nature, 406, 54-56. https://doi.org/10.1038/35017531

Hussain, S. M., Afzal, M., Nasir, S., Javid, A., Azmat, H., Makhdoom, S. M., ... Iqbal, M. (2017). Role of phytase supplementation in improving nutrient digestibility and growth performance for Labeorohita fingerlings fed on canola meal based diet. Journal of Applied Animal Research, 45(1), 15-21. https://doi.org/10.1080/09712119.2015.1091331

Islam, M. S. (2005). Nitrogen and phosphorus budget in coastal and marine cageaquaculture and impacts of effluent loading on ecosystem: Review andanalysis towards model development. Marine Pollution Bulletin, 50(1), 48-61. https://doi.org/10.1016/j.marpolbul.2004.08.008

Jahan, P., Watanabe, T., Kiron, I., \& Satoh, S. H. (2003). Balancing protein ingredients in carp feeds to limit discharge of phosphorus and nitrogen into water bodies. Fisheries Science, 69, 226-233. https://doi.org/ 10.1046/j.1444-2906.2003.00612.x

Jahan, P., Watanabe, T., Satoh, S., \& Kiron, V. (2002). Different combinations of protein ingredients in carp diets for reducing phosphorus loading. Fisheries Science, 68, 595-602. https://doi.org/10.1046/j.1444-2906. 2002.00466.x

Jirasek, J., Mares, J., \& Zeman, L. (2005). Nutrition requirement and tables of fish feed nutritive value. Final Report MZLU, Brno.

Jobling, M., Gomes, E., \& Dias, J. (2001). Feed types, manufacture and ingredients. In D. Houlihan, T. Boujard, \& M. Jobling (Eds.), Foodintake in fish (pp. 25-48). Oxford, UK: Blackwell Science. https://doi.org/ 10.1002/9780470999516.ch2

Johnsen, F., Hillestad, M., \& Austreng, E. (1993). High energy diets for Atlantic salmon. Effects on pollution. In S. J. Kaushik, \& P. Luquet (Eds.), Fish nutrition in practice (pp. 391-402, Les Colloques No. 61). INRA, Versailles Cedex, France.

Kaushik, S. J. (1998). Nutritional bioenergetics and estimation of waste production in non-salmonids. Aquatic Living Resources, 11(4), 211-217. https://doi.org/10.1016/S0990-7440(98)89003-7

Keshavanath, P., Manjappa, K., \& Gangadhara, B. (2002). Evaluation of carbohydrate rich diets through commoncarp culture in manured tanks. Aquaculture Nutrition, 8(3), 169-174. https://doi.org/10.1046/ j.1365-2095.2002.00202.x

Kirimi, J. G., Musalia, L. M., Magana, A., \& Munguti, J. M. (2020). Protein quality of rations for Nile tilapia (Oreochromis niloticus) containing oilseed meals. Journal of Agricultural Science, 12(2), 82-91. https://doi.org/10.5539/jas.v12n2p82

KNBS (Kenya National Bureau of Statistics). (2019). Economic survey Nairobi (p. 333). Kenya National Bureau of Statistics, Kenya. Retrieved from http://www.devolutionplanning.go.ke/images/hb/EconomicSurvey 2019.pdf

Lazzari, R., \& Baldisserotto, B. (2008). Nitrogen and phosphorus waste in fish farming. Bol Inst Pesca, 34(4), 591-600.

Leon, J. N. (2006). Synopsis of salmon farming impacts and environmental management in Chile (p. 46). Consultancy Technical Report. WWF, Valdivia, Chile.

Li, P., Mai, K., Trushenski, J., \& Wu, G. (2009). New developmentsin fish amino acid nutrition: Towards functional and environmentally oriented aquafeeds. Amino Acids, 37, 43-53. https://doi.org/10.1007/ s00726-008-0171-1 
Liti, D. M., Mugo, R. M., Munguti, J. M., \& Waidbacher, H. (2006). Growth and economic performance of Nile tilapia (Oreochromis niloticusL.) fed on three brans (maize, wheat and rice) in fertilized ponds. Aquaculture Nutrition, 12(3), 239-245. https://doi.org/10.1111/j.1365-2095.2006.00397.x

Lynch, P. B., \& Caffrey, P. J. (1997). Phosphorus requirements for animal production. In H. Tunney, O. T. Carton, P. C. Brookes, \& A. E. Johnston (Eds.), Phosphorus Loss from Soil to Water (pp. 283-296). CAB International, New York, USA.

Makkar, H. P. S. (1993). Anti-nutritional factors in foods for livestock. In M. Gill, E. Owen, G. E. Pollot \& T. L. J. Lawrence (Eds.), Animal production in developing countries (Occasional Publication No. 16, pp. 69-85). British Society of Animal Production. https://doi.org/10.1017/S0263967X00031086

Mbugua, M. H. (2008). Status, challenges and opportunities. Aquaculture in Kenya (p. 10). Nairobi: State Department of Fisheries.

Mente, E., Pierce, G. J., Santos, M. B., \& Neofitou, C. (2006). Effect of feed and feeding in culture of salmonids on the marine aquatic environment: A synthesis for European aquaculture. Aquaculture International, 14, 499-522. https://doi.org/0.1007/s10499-006-9051-4

Munguti, J. M., Kim, J., \& Ogello, E. O. (2014). An overview of Kenyan aquaculture sector; current status, challenges and opportunities for future development. Fisheries and Aquatic Sciences, 17(1), 1-11. https://doi.org/10.5657/FAS.2014.0001

Musyoka, S. N., Liti, D. M., Ogello, E., \& Waidbacher, H. (2019). Utilization of the earthworm, Eisenia fetida (Savigny, 1826) as an alternative protein source in fish feeds processing: A review. Aquaculture Research, 50(9), 2301-2315. https://doi.org/10.1111/are.14091

Naylor, R. L., Goldburg, R. J., Primavera, J. H., Kautsky, N., Beveridge, M.C.M., Clay, J., ... Troell, M. (2000). Effect of aquaculture on world fish supplies. Nature, 405, 1017-1024. https://doi.org/10.1038/35016500

Ngugi, C. C., Bowman, J. R., \& Omolo, B. O. (2007). A new guide to fish farming in Kenya. Aquaculture Collaborative Research Support Program, Nairobi, Kenya.

Njiru, J. M., Aura, C. M., \& Okechi, J. K. (2018). Cage fish culture in Lake Victoria: A boon or a disaster in waiting? Fisheries Management and Ecology, 26(5), 426-434. https://doi.org/10.1111/fme.12283

NRC. (1993). Nutrients requirements of fish. National Academy Press, Washington, D.C., USA.

Nunes, A. J. P., Sa, M. V. C., Browdy, C. L., \& Vazpuez-Anon, M. (2014). Practical supplementation of shrimp andfish feeds with crystallineamino acids. Aquaculture, 431, 20-27. https://doi.org/10.1016/j.aquaculture. 2014.04.003

Obiero, K., Meulenbroek, P., Drexler, S., Dagne, A., Akoll, P., Odong, R., ... Waidbacher, H. (2019). The contribution of fish to food and nutrition security in Eastern Africa: Emerging trends and future outlooks. Sustainability, 1636(11), 1-15. https://doi.org/10.3390/su11061636

Ogello, E. O., \& Munguti, J. M. (2016). Aquaculture: A promising solution for food insecurity, poverty and malnutrition in Kenya. African Journal of Food Agriculture, Nutrition and Development, 16(4), 11332-11351. https://doi.org/10.18697/ajfand.76.15900

Olsen, L. M., Holmer, M., \& Olsen, Y. (2008). Perspectives of nutrient emission from fish aquaculture in coastal waters: Literature review with evaluated state of knowledge. FHF Project No. 542014. https://doi.org/ 10.13140/RG.2.1.1273.8006

Portz, L., \& Liebert, F., (2004). Growth, nutrient utilization and parameters of mineral metabolism in Nile tilapia Oreochromis niloticus (Linneaus, 1758) fed plant based with graded levels of microbial phytase. Journal of Animal Physiology and Animal Nutrition, 88(9-10), 311-320. https://doi.org/10.1111/j.1439-0396.2004. 00486.x

Ravindran, V., Ravindran, G., \& Sivalogan, S. (1994). Total and phytate phosphorus contents of various foods and feedstuffs of plant origin. Food Chemistry, 50, 133-136. https://doi.org/10.1016/0308-8146(94)90109-0

Rodehutscord, M., Gregus, Z., \& Pfeffer, E. (2000). Effect of phosphorus intake on faecal and non-faecal phosphorus excretion in rainbow trout (Oncorhynchus mykiss) and the consequences for comparative phosphorus availability studies. Aquaculture, Amsterdam, 188, 383-398. https://doi.org/10.1016/S00448486(00)00341-0 
Satoh, S., Hernandez, A., Tokoro, T., Morishita, Y., Kiron, V., \& Watanabe, T. (2003). Comparison of phosphorus retention efficiency between rainbow trout (Oncorhynchus mykiss) fed a commercial diet and a low fish meal based diet. Aquaculture, 224(1)271-282. https://doi.org/10.1016/S0044-8486(03)00217-5

Sugiura, S. H., Babbitt, J. K., Dong, F. M., \& Hardy, R. W. (2000). Utilization of fish and animal by-product meals in low pollution feeds for rainbow trout Oncorhynchus mykiss (Walbaum). Aquaculture Research, 31(7), 585-593. https://doi.org/10.1046/j.1365-2109.2000.00476.x

Suryaningrum, L. H., Dedi, J., Setiawati, M., \& Sunarno, D. M (2017). Nutrient composition and apparent digestibility coefficient of Ulva lactuca meal in the Nile tilapia (Oreochromisniloticus). AACL Bioflux, 10(1), 77-86. http://www.bioflux.com.ro/aacl

Tucker, C. S., Hargreaves, J. A., \& Boyd, C. E. (2001). Management of effluents from catfish ponds. West Virginia: Aquacultural Engineering Society Issues Forum, Shepardstown.

Turcios, A. E., \& Papenbrock, J. (2014). Sustainable treatment of aquaculture effluents-what can we learn from the past for the future. Sustainability, 6(2), 836-856. https://doi.org/10.3390/su6020836

Verdegem, M. C. J., Eding, E. H., \& Verreth, J. V. J (2001). Towards improved sustainability in ponds and recirculation systems. Proceedings of the international workshop on aquaculture and environment, Cochin, India.

Vielma, J., Ruohonen, K., \& Peisker, M. (2002). Dephytinization of two soy proteins increases phosphorus and protein utilization by rainbow trout, Oncorhynchus mykiss. Aquaculture, 204(1-2), 145-156. https://doi.org/ 10.1016/S0044-8486(01)00653-6

Waite, R., Beveridge, M., Brummett, R., Castine, S., Chaiyawannakarn, N., Kaushik, S., ... Phillips, M. (2014). Increasing productivity of aquaculture. Working paper, installment 6 of creating a sustainable food future. Washington, D.C. World Resources Institute.

White, P. (2013). Environmental consequences of poor feed quality and feed management. In M. R. Hasan \& M. B. New (Eds.), On-farm feeding and feed management inaquaculture (FAO Fisheries and Aquaculture Technical Paper No. 583, pp. 553-564). Rome, FAO.

White, P., Christensen, G. N., Palerud, R., Legovic, T., Rosario, W., Lopez, N., ... Hernandez, J. (2007). Environmental monitoring and modelling of aquaculture in risk areas of the Philippines (p. 52). EMMA Final Report. Bolinao Akvaplan-niva AS, Tromso, Norway.

Yildiz1, H. Y., Robaina, L., Pirhonen, J., Mente, L., Domínguez, D., \& Parisi, G. (2017). Fish welfare inaquaponic systems: Its relation to water quality with an emphasis on feed and faeces-A review. Water, 9(13), 1-17. https://doi.org/10.3390/w9010013

\section{Copyrights}

Copyright for this article is retained by the author(s), with first publication rights granted to the journal.

This is an open-access article distributed under the terms and conditions of the Creative Commons Attribution license (http://creativecommons.org/licenses/by/4.0/). 